undres over den rolle legitimering og religion spiller i værket.

Det epokegørende nye i Leviathan er, at Hobbes ikke baserer kongens position - og dermed også samfundets enhed, dets sammenhængskraft - på teologisk-politiske argumenter omkring tradition, guddommelig ret, blodets arvefølge eller lignende. I stedet hviler autoriteten på et rent sekulært grundlag: på nytte og effektivitet. Eller rettere, han tager religionens virkemidler og begrundelsesformer og anvender dem i en sekulær kontekst. Hobbes anvender religionens suggestive kraft til sekulære formål. Den enorme kraft heri observerede han under den engelske borgerkrig, som han beskriver i komplementarværket til Leviathan, nemlig i Behemoth, der underligt nok slet ikke nævnes $\mathrm{i}$ introduktionen, men som er uomgængeligt for at forstå Hobbes' forhold til og anvendelse af religion og for at forstå de to sidste dele af Leviathan, der handler om kristendommen og mørkets rige. Introduktionen følger de gængse læsninger af Hobbes ved stort set at ignorere disse dele.

De kritiske kommentarer til introduktionen skal ikke fjerne fokus fra, at dette er en kraftpræstation af oversætteren og et meget velkomment bidrag til filosofisk og politisk interesserede i Danmark. Nu er der ingen undskyldning for ikke at komme i gang med den udfordring, Hobbes stillede os overfor for 350 år siden, nemlig forholdet mellem individ og stat, mellem lydighed og beskyttelse samt mellem religion og politik.

Mikeel Thorup

\section{Fra korstog til kortslutning}

Adrian Desmond \& James Moore: Darwin's Sacred Cause: Race, Slavery and the Quest for Human Origins. Allen Lane, 2009. 512 sider. £25.

Hvor mange buzzwords er det muligt at presse ind i en bogtitel? Med udgivelsen af Adrian Desmond og James Moores Darwin's Sacred Cause: Race, Slavery and the Quest for Human Origins må forlaget Allen Lane være tæt på en rekord. Faktisk er det kun de tre små limord "and", "the" og "for", der ikke tænder opmærksomhedslamperne. "Darwin" sælger i 2009. Kombinationen med "hellig sag" eller "hellig grund" sælger endnu mere. Når det så kan skrues sammen med de politisk ømme "race" og "slaveri" og forbindes til en "kamp om menneskets oprindelse" af det notoriske Darwincelebrity-par Desmond \& Moore, ja, så burde succesen være hjemme. I hvert fald den økonomiske.

Der er ingen tvivl om, at bogen vil blive solgt på titel og bagsidetekst. Spørgsmålet er så, om den vil blive læst - og hvordan den vil blive læst. Bogen blev allerede i efteråret 2008 hypet som et af de vigtigste bidrag til Darwinåret i 2009. Det var store ord om en bog, som på det tidspunkt endnu ikke engang var skrevet færdig. 
Men man har villet være sikre på, at markedet var klar over, hvad der var på vej, og har med en udgivelsesdato d. 29. januar 2009 placeret sig perfekt for opmærksomheden, inden det hele drukner i Darwinkonfetti, selvsmagende receptioner, højtidelige taler og anden støj. Forlaget har ønsket at ride på bølgen fra starten — og det med intet mindre end en sensation: Darwin udviklede i virkeligheden sin evolutionsteori, fordi han hadede slaveri.

Der er fuld fart over feltet i historien om kampen mod slaveri, hvor Darwin sættes i centrum for en fortælling, der spænder over hele kloden — uden at det faste ankerpunkt i det britiske imperium nogensinde forlades. Vi følger Darwin gennem medicinuddannelsen i Edinburgh, teologiuddannelsen og den medfølgende naturhistoriske dannelse i Cambridge over Beaglerejsen jorden rundt til London og endelig Down House. Men det er langt fra en biografi. Hele tiden holdes slavespørgsmålet $\mathrm{i}$ det spændte og spændende fortællecentrum. Darwins interesse for fossiler, skeletter, biller, orkideer og rankefødder toner umærkeligt væk for en verden fuld af forskellige folkeslag, hvordan de skal behandles og hvordan en fuld videnskabelig forståelse af dem kan se ud.

Det er i vanlig videnskab-er-intetandet-end-social-kamp stil, at Desmond og Moore hvirvler læseren ind i, hvad de selv mener, er en overbevisende argumentation. Men i løbet af læsningen af de godt 500 sider bliver det mere og mere til en insisterende argumentation. Jeg tror aldrig, at jeg før har læst en bog med så mange indskudte hvis, måske, sandsynligvis, så-ville-han, så-kunne-han, så-er-detnærliggende-at-tro, osv. Og det er virkelig synd, for Desmond og Moore har her fat $i$ et utrolig vigtigt og alt for underbelyst emne. Men der er to fristelser, der desværre forhindrer dette $i$ at blive en rigtig god bog: dels vil de med al vold og magt skabe en sensation, og dels vil de partout have placeret Darwin i alle mulige sammenhænge og diskussioner, hvor slavespørgsmålet dukkede op i første halvdel af 1800-tallet. Vi får derfor en sværm af folk, der bliver introduceret i forhold til, hvor langt de boede fra Darwin selv, eller fra familiemedlemmer, hvordan de kendte venner af familien, eller havde skrevet $i$ et tidsskrift, som Darwins undervisere også skrev i, men på et andet tidspunkt, osv., osv. Det bliver hurtigt trættende, særligt fordi det faktisk er unødvendigt. Desmond og Moore ville have vundet meget ved at skrive historien om, hvordan slavespørgsmålet blev diskuteret $i$ tiden på kryds og tværs og af alle mulige forskellige uden at skrive Darwin ind i den, så læseren selv kunne placere ham. $\mathrm{Nu}$ føles det næsten som en slags "Find Holger", hvor forfatterne alligevel ikke kan lade være med at røbe, hvor de har stillet ham.

I den proces er der også alt for mange glidninger, hvor noget bliver introduceret som en mulighed og så 
over nogle sider bliver til en etableret kendsgerning. Et eksempel på "glidningerne" tager udgangspunkt i $D e-$ scent of Man, hvor Darwin omtaler forskellene mellem folkeslag og henviser til, at der ikke var særlig stor forskel på europæere og de tre personer fra Tierra del Fuego, der rejste med HMS Beagle, og "a full-blooded negro with whom I once happened to be intimate". Darwin hentyder til den frigivne slave, som i Edinburgh lærte ham at udstoppe fugle. Det bliver efterhånden hos Desmond og Moore til "an intimate", dvs. forholdet går fra, hvad Darwin beskriver som et bekendtskab til et, som forfatterne beskriver som et fortrolighedsforhold. Og uanset hvor sympatisk indstillet Darwin var over for sin sorte ven, så har vi intet vidnesbyrd, der dokumenterer, at de skulle være fortrolige.

Et andet trick, Desmond og Moore benytter sig af, er at live deres prosa op med masser af sætningsstykker og ofte bare enkelte ord, som de gavmildt deler ud af fra et væld af kilder. Da de samler bunker af kilder i enkelte noter, betyder det for det første, at det er ualmindelig vanskeligt først at identificere og senere lokalisere sætningsfragmenterne. Hvis man alligevel kæmper sig igennem, når man alt for ofte til et andet resultat end forfatterne. I sin Selvbiografi skriver Darwin blandt andet om sit forhold til onklen Josiah Wedgwood. Det bliver hos Desmond og Moore til "No 'power on earth', Charles knew, could make Jos 'swerve an inch from what he considered the right course', least of all about slavery" (s. 60). Problemet er her bare, at Darwin på intet tidspunkt taler om slaveri i forbindelse med sit forhold til onklen. Men læseren forledes naturligt nok til at tro, at det netop er det, Darwin mener. Helt galt går det $i$ finalen, hvor antislaveri-fortaleren Thomas Clarkson bliver hevet ind som indbegrebet af "Darwin's Sacred Cause". Clarkson angiveligt "sat at the top of Darwin's pantheon - he was the Newton or Shakespeare of Darwin's moral cosmos". Newton og Shakespeare er jo ikke hvem som helst. Hvis Clarkson virkelig spillede den rolle, er det så ikke ejendommeligt, at han aldrig nogensinde blev nævnt af Darwin? Hvorfor holde sin største helt hemmelig?

Men hemmelighedskræmmeriet er en fast del af Desmond og Moores overordnede fortolkningsstrategi: Darwin holdt sin teori hemmelig og blev syg. I jagten på sociale og psykologiske fortolkninger skæres hjørner, og for at det hele skal passe, er udvalget af den sekundære litteratur meget nøje tilpasset deres konklusioner. Et grelt eksempel er diskussionen af frenologien, der spiller en helt central rolle i bogen. Her holdes historien fast som et spørgsmål om nogle unge, radikale og reformivrige samfundsomstyrtere, der havde fundet en videnskab, der passede til deres sociale dagsorden. Dækningen for det kommer fra Steven Shapins studier af Edinburghfrenologerne fra midten af 1970'erne. Geoffrey Can- 
tors meget kritiske respons ignoreres og alle de mange senere studier forbigås også bekvemt - uheldigt, da de fortæller en helt anden historie.

Når alt det er sagt, så sidder man ved endt læsning med en dobbelt følelse. Desmond og Moore er igennem så meget vigtigt, spændende og rigt materiale. Man lærer helt utrolig meget af bogen. Men det er lidt ligesom fyrværkeri i Tivoli nytårsaften. Hvis man ikke ved, hvad man har med at gøre, så kan det gå grueligt galt.

Peter C. Kjargaard 